\title{
Long-lasting analgesic effect of the psychedelic drug changa: A case report
}

\author{
GENÍS ONA ${ }^{1 *}$ and SEBASTIÁN TRONCOSO ${ }^{2}$ \\ ${ }^{1}$ Department of Anthropology, Philosophy and Social Work, Universitat Rovira i Virgili, Tarragona, Spain \\ ${ }^{2}$ Independent Researcher
}

(Received: August 23, 2018; accepted: January 8, 2019)

\begin{abstract}
Background and aims: Pain is the most prevalent symptom of a health condition, and it is inappropriately treated in many cases. Here, we present a case report in which we observe a long-lasting analgesic effect produced by changa, a psychedelic drug that contains the psychoactive N,N-dimethyltryptamine and ground seeds of Peganum harmala, which are rich in $\beta$-carbolines. Methods: We describe the case and offer a brief review of supportive findings. Results: A long-lasting analgesic effect after the use of changa was reported. Possible analgesic mechanisms are discussed. We suggest that both pharmacological and non-pharmacological factors could be involved. Conclusion: These findings offer preliminary evidence of the analgesic effect of changa, but due to its complex pharmacological actions, involving many neurotransmitter systems, further research is needed in order to establish the specific mechanisms at work.
\end{abstract}

Keywords: analgesic, pain, psychedelic, psychoactive, DMT, $\beta$-carboline alkaloids

\section{INTRODUCTION}

The treatment of pain is one of the most significant challenges in the history of medicine. At present, there are still many challenges that hamper pain's appropriate treatment, as recently stated by American Pain Society (Gereau et al., 2014). Paradoxically, while we are presented with analgesic undertreatment (Deandrea, Montanari, Moja, \& Apolone, 2008; Greco et al., 2014), the abuse of opioid medications has led to the current opioid crisis that many countries are facing (National Institute on Drug Abuse, 2018).

Pain has several psychological and physical consequences. It is the most prevalent symptom of an underlying health problem, affecting 100 million people in the United States (Institute of Medicine, 2011) and 95 million people in Europe (Boston Scientific, 2013). It is also the most underrecognized and undertreated medical problem of the 21st century (European Pain Federation, 2018).

Changa is a smoking mixture that contains $\mathrm{N}, \mathrm{N}$-dimethyltryptamine (DMT; generally extracted from Mimosa hostilis) and $\beta$-carbolines (extracted from Banisteriopsis caapi or Peganum harmala). The mechanisms of action for these compounds are quite similar to those found in the ayahuasca beverage (McKenna \& Riba, 2015), with possible differences in constituents if $P$. harmala is used instead of $B$. caapi. In the case of $P$. harmala, as mentioned below, ground seeds were used in the case reported. The compounds found in seeds of this plant are $\beta$-carbolines (harmaline, harmine, harmalol, tetrahydroharmine, and harmol; Herraiz, González, Ancín-Azpilicueta, Arán, \& Guillén, 2010) and quinazolines (mainly vasicine; Herraiz, Guillén, Arán, \& Salgado, 2017). The psychoactive effects of ayahuasca usually last between 3 and $5 \mathrm{hr}$ (McKenna \& Riba, 2015), but the effects of smoked changa last about 15-30 min (Ott, 1994).

\section{CASE DESCRIPTION}

$\mathrm{JM}$ is a 57-year-old adult male who works as a doctor at a public hospital in Spain. He developed some signs of musculoskeletal pain, especially in his limbs, and fatigue 10 years ago. These symptoms slowly increased and became more extensive until they reached disabling levels. The muscular pain limited him to moderate exercise, as it took him almost 1 week to completely recover from performing physical activity. JM also developed sleep disorders, waking up in the night due to pain. After working a night shift in the hospital's emergency services, he again needed 1 week to recover physically and in terms of his sleep rhythm. Regarding his sexual life, it took a lot of effort for him to even caress his spouse because of the muscular pain in his arms. After intercourse, he also needed 1 week to recover, and ejaculation was painful, so he experienced decreased sexual desire. Other symptoms included an inability to lift heavy weights, decreased attentiveness, and vision with muted colors.

He decided to visit a rheumatologist 3 years ago and was diagnosed with fibromyalgia and chronic fatigue. In the

* Corresponding author: Genís Ona; Department of Anthropology, Philosophy and Social Work, Universitat Rovira i Virgili, Campus Catalunya URV, Avda. Catalunya, 35, 43005, Tarragona, Spain; Phone: +34 675553 344; E-mail: gona_est@hotmail.com

This is an open-access article distributed under the terms of the Creative Commons Attribution-NonCommercial 4.0 International License, which permits unrestricted use, distribution, and reproduction in any medium for non-commercial purposes, provided the original author and source are credited, a link to the CC License is provided, and changes - if any - are indicated. 
following months, JM was prescribed ibuprofen, diclofenac, and dexketoprofen. However, taking these drugs resulted in little or no improvement. His rheumatologist recommended that he attend a workshop that was taking place in an ambulatory clinic setting. The workshop consisted of 2 months of training in cognitive therapy for fibromyalgia patients. JM completed the training, after which his level of pain decreased from 8 to 3 on the numerical rating scale (which ranges from 0 to 10 ). However, a couple of weeks later, the pain and fatigue had increased again. He was then prescribed ozone therapy and fluoxetine. Ozone therapy relieved his pain but only for a couple of days. Fluoxetine, however, was effective for both pain and fatigue, assisting JM to attain a rating of 3-4 on the pain scale again. Nevertheless, after 6 weeks of treatment, he decided to stop taking fluoxetine, because he developed autolytic ideation and annoying rumination, the symptoms that he had not previously experienced.

His drug history includes only one instance of consuming ayahuasca 5 years ago. JM decided to take changa with an underground therapist 3 months ago. The changa session involves an evening meeting. Approximately $30 \mathrm{~min}$ of meditation precedes consumption. Then, each individual presented (generally four or five people participated) smokes one previously prepared cigarette that contains freebase DMT and ground seeds of $P$. harmala (the content of the cigarette was confirmed through a harm-reduction organization that analyzed a sample using gas chromatographymass spectrometry). JM has attended five changa sessions so far. In the first session, he was only able to relax, because he did not know how to smoke. In the second session, 1 week later, he could smoke correctly and felt intense psychoactive effects. After this session, his pain disappeared almost completely for a period of 2 weeks. After the third session, which further took place after 2 weeks, his mood had also improved. The autolytic ideation disappeared and he felt much better. According to him, he was able to see colors brightly again. He had the same results after his fourth session, which took place 15 days after the previous one. After that session, he reported greater emotional stability, pain relief, and a slight decrease in fatigue as well. He participated in another changa session 1 month later, after which he confirmed the decrease in pain that lasted up to 15 days.

\section{DISCUSSION}

We can suggest various mechanisms through which changa may exert an analgesic effect. In this case, freebase DMT extracted from $M$. hostilis was used. DMT is an indole alkaloid widely found in plants and in mammals, including humans (Barker, McIlhenny, \& Strassman, 2012; Beaton \& Christian, 1977; Saavedra \& Axelrod, 1972; Servillo, Giovane, Balestrieri, Cautela, \& Castaldo, 2012). It is a partial agonist of serotonin $(5-\mathrm{HT})$ receptors $(1 \mathrm{~A}, 2 \mathrm{~A}$ and $2 \mathrm{C}$; Keiser et al., 2009) and also an agonist of sigma-1 receptors $\left(\sigma_{1} R\right.$; Fontanilla et al., 2009). It interacts with other receptors indirectly as well (for a review, see Carbonaro \& Gatch, 2016).
Regarding the agonism on 5-HT receptors, the relationship between mood and pain is well known (Marsden, 1979), so an elevation of mood produced by DMT could partially explain its analgesic effect. This is also relevant regarding the efficacy of fluoxetine, as was observed in this case. It has been observed that anti-depressant drugs have an analgesic effect that is independent of their effect on mood (Jann \& Slade, 2007; Mico, Ardid, Berrocosso, \& Eschalier, 2006). However, it seems that tricyclic anti-depressants and serotonin-noradrenaline reuptake inhibitors are more effective than selective serotonin reuptake inhibitors for the treatment of pain (Jann \& Slade, 2007; Stahl, Grady, Moret, \& Briley, 2005). This suggests that noradrenergic pathways are highly relevant to the management of pain (Benson et al., 2015).

Concerning $\sigma_{1} R$, this orphan receptor is distributed throughout the central nervous system, heart, liver, and lungs (Hayashi \& Su, 2007), and it has been observed to play a role in several conditions, such as addiction, depression, amnesia, cancer, and pain (Collier, Waterhouse, \& Kassiou, 2007). At the endoplasmic reticulum, it acts as a ligand-operated chaperone protein, regulating the flow of $\mathrm{Ca}^{2+}$ via inositol 1,4,5-triphosphate receptors (Hayashi \& Su, 2007; Su, Hayashi, Maurice, Buch, \& Ruoho, 2010). In the plasma membrane, it can modulate the activity of opioid and N-methyl-D-aspartate receptors, as well as $\mathrm{K}^{+}$and $\mathrm{Ca}^{2+}$ channels (Zamanillo, Romero, Merlos, \& Vela, 2013). Its activity can be modulated by $\sigma_{1} \mathrm{R}$ ligands, which are expressed in areas associated with pain control, such as dorsal root ganglion neurons, dorsal spinal cord, the thalamus, the periaqueductal gray, and the rostroventral medulla (Gundlach, Largent, \& Snyder, 1986). There are various genetic and pharmacological findings that provide sufficient evidence to consider $\sigma_{1} \mathrm{R}$ antagonists as part of an innovative approach for the treatment of pain (Vela, Merlos, \& Almansa, 2015). In fact, the first phase II, randomized, placebo-controlled clinical trial in which a $\sigma_{1} \mathrm{R}$ antagonist (MR309) was used reported encouraging results (Bruna et al., 2018). However, other studies also reported an analgesic effect of $\sigma_{1} \mathrm{R}$ agonists in terms of neuropathic pain (Ohsawa, Hayashi, \& Kamei, 2010; Tomohisa et al., 2015). Thus, the underlying mechanism for the analgesic effects of the agonism/antagonism of $\sigma_{1} \mathrm{R}$ has not yet been fully clarified. Ohsawa et al. (2010) suggested that the anti-nociceptive effect of the $\sigma_{1} R$ agonist that was used in their study (pentazocine) involves the lowering of nitric oxide metabolites. The effect was likely produced due to a dose effect (the peripheral application of pentazocine may produce the nociceptive response at a lower dose, whereas higher doses, such as those used in the study, produce an inverse effect; Ohsawa et al., 2010). Tomohisa et al. (2015) used $\sigma_{1} \mathrm{R}$ agonist SA4503 in their study. Interestingly, SA-4503 and not NE-100 (a $\sigma_{1} \mathrm{R}$ antagonist) produced anti-nociceptive effects in terms of chemotherapeutic-induced neuropathic pain. To explain this finding, the authors mention the cytoprotective and neuroprotective effects of $\sigma_{1} \mathrm{R}$ agonists (Griesmaier et al., 2012; Hyrskyluoto et al., 2013; Ono et al., 2014; Tuerxun et al., 2010), which may influence the anti-neuropathic effects. Furthermore, DMT also reduces inflammation via $\sigma_{1} \mathrm{R}$ (Szabo, Kovacs, Frecska, \& Rajnavolgyi, 2014). It has been 
observed that inflammation response can induce pain, and that inflammatory signals can induce changes in neurotransmitter metabolism, neuroendocrine function, and neuroplasticity (Walker, Kavelaars, Heijnen, \& Dantzer, 2014). In this respect, DMT can also induce neuronal plasticity (Kourrich, Su, Fujimoto, \& Bonci, 2012; Ly et al., 2018; Ruscher et al., 2011; Tsai et al., 2009), which can play a vital role in the treatment of pain (Price, Verne, \& Schwartz, 2006; Sibille, Bartsch, Reddy, Fillingim, \& Keil, 2016).

The ground seeds of $P$. harmala are the other constituent of changa. They contain many $\beta$-carbolines and quinazolines, with harmaline being the major alkaloid (Mahmoudian, Jalilpour, \& Salehian, 2002). It has been observed that these $\beta$-carbolines bind with modest affinity to $5-\mathrm{HT}_{2 \mathrm{~A}}$ receptors (Riba, 2003), except in the case of harmine, which expresses high affinity with these receptors (Glennon et al., 2000). They also show affinity for 5-HT $2 \mathrm{C}, 1 \mathrm{~A}$, dopamine (Nasehi et al., 2010), gammaaminobutyric acid (GABA; Glennon et al., 2000), imidazoline ( $\mathrm{I}_{2} ; \mathrm{Yu}$, Idle, Krausz, Küpfer, \& Gonzalez, 2003), and adrenergic $\left(\alpha_{2}\right)$ receptors (Husbands et al., 2001). These $\beta$-carbolines can also interact with opioid receptors (Farouk, Laroubi, Aboufatima, Benharref, \& Chait, 2008). However, the most remarkable is their ability to inhibit the enzyme monoamine oxidase (MAO) at concentrations in the micromolar and nanomolar range (Riba, 2003). These substances appear to be more effective at inhibiting MAO-A than at inhibiting MAO-B.

The seeds of $P$. harmala have been traditionally used (Akhtar, Iqbal, Khan, \& Lateef, 2000) for the treatment of various types of pain (Moloudizargari, Mikaili, Aghajanshakeri, Asghari, \& Shayegh, 2013). Recent studies have verified the analgesic potential of $P$. harmala seeds using three different extracts and pain models (Farouk et al., 2008; Monsef, Ghobadi, Iranshahi, \& Abdollahi, 2004; Sokmen, Jones, \& Erturk, 1999), showing that the butanolic extract had the maximum effect in the writhing test. Pretreatment with naloxone prevented the extracts from having a nociceptive effect, so it was concluded that an opioid-modulated mechanism is involved.

Apart from the possible synergy with DMT's effects on 5-HT release, and therefore the aforementioned potential analgesic effect, $\beta$-carbolines also interact with receptors closely related to pain modulation, such as GABA (Munro, Hansen, \& Mirza, 2013), I 2 (Bektas, Nemutlu, \& Arslan, 2015), $\alpha_{2}$ (Carroll, Mackey, \& Gaeta, 2007), and opioid receptors (Kirkpatrick et al., 2015). Complex interactions between these receptors are also possible, since $\mathrm{I}_{2}$ can potentiate analgesic actions produced by opioid receptor ligands (Bektas et al., 2015). Furthermore, two studies demonstrated the neuroprotective effects of the alkaloids of P. harmala (Herraiz \& Guillén, 2011; Splettstoesser, Bonnet, Wiemann, Bingmann, \& Büsselberg, 2005), which could also be related to their analgesic effects (Mannelli et al., 2009).

Regarding the ability of $\beta$-carbolines to inhibit the MAO-A enzyme, although some authors indicate that MAO inhibitors should not be used in the treatment of pain (Mika, Zychowska, Makuch, Rojewska, \& Przewlocka, 2013), MAO inhibitors like phenelzine have been shown to be effective for treating pain associated with depression
(Davidson, 1985). Moreover, specific MAO-A inhibitors could have greater analgesic effects (Menkes, Fawcett, Busch, \& Jones, 1995), since these specific inhibitors increase norepinephrine, DA, and 5-HT levels in the tissues (da Prada et al., 1990).

The major quinazoline present in $P$. harmala seeds is vasicine, which has been shown to produce significant anti-inflammatory effects (Singh \& Sharma, 2013), which can also be related to its analgesic effects.

As discussed above, we cannot dismiss the possibility that the active constituents in changa produce a direct analgesic effect. However, those compounds have short half-lives $\left(t_{1 / 2 \lambda z}=260-532 \mathrm{~min}\right.$; Riba, 2003) that are insufficient to explain the pattern that can be clearly observed in the case: an analgesic effect that endured for over 2 weeks. It is well known that a single administration of a psychedelic drug, such as psilocybin, can produce longlasting effects (Griffiths et al., 2011). The mechanisms underlying these long-lasting effects are not well understood, but they have been correlated with psychological factors like peak experiences (Bogenschutz et al., 2015; García-Romeu, Griffiths, \& Johnson, 2014; Griffiths et al., 2011) or an enhancement of the placebo effect (Hartogsohn, 2016). Regarding the latter, it is well known that psychedelics can increase suggestibility in human subjects (Carhart-Harris et al., 2015; de Rios, Grob, \& Baker, 2002), so it is reasonable to think that the variables found in the ritualistic setting in which changa was provided, like expectancy or attentive and respectful listening by caregivers, together with the fact that there could be a real, short-term analgesic effect, probably exert a magnified placebo effect. Furthermore, a recently published review suggests that psychedelic drugs like lysergic acid diethylamide and psilocybin may alleviate malignant and neuropathic pain (Whelan \& Johnson, 2018). The authors argue that this effect could be related to the psychedelic experience itself, which can modify the metacognitive interpretation of pain. Some authors have suggested that epigenetic modifications (Schindler, Wallace, Sloshower, \& D'souza, 2018), as well as neuroplasticity and neurogenesis (Ezquerra-Romano, Lawn, Krupitsky, \& Morgan, 2018; Ly et al., 2018), could trigger long-lasting responses.

Due to the complexity of the pharmacological effects produced by changa's constituents, more research will be needed in order to clarify the specific mechanisms through which long-lasting analgesic effects can be produced. It will also be significant to describe other indirectly affected systems, such as modifications of opioid receptor density or alterations of 5-HT binding sites, among many other systems that are hypothesized to be affected by changa's constituents. In addition, the analgesic effect of ayahuasca was reported (Barbosa, Cazorla, Giglio, \& Strassman, 2009), suggesting similar mechanisms of action.

\section{CONCLUSIONS}

The intense psychedelic effects of changa limit its application in clinical contexts. However, the case reported here suggests that changa can produce a long-lasting analgesic 
effect, involving a combination of mood-enhancing effects; other psychological factors; an interaction with several neurotransmitter systems; and anti-inflammatory, neuroprotective, and plasticity-promoting actions. Remarkably, changa could offer pain treatment that targets multiple monoamine neurotransmitters, as recommended by some authors (Benson et al., 2015).

Further research on the bioavailability of changa constituents based on the smoking procedure that is used is also warranted.

Acknowledgements: This research received no specific grant from any funding agency in the public, commercial, or notfor-profit sectors. GO wrote the first draft of the manuscript. GO and ST conceived this case report and interviewed the patient. They also reviewed and approved the final version of the manuscript.

Ethics: This study was conducted following the principles of the Declaration of Helsinki, and the patient's informed consent was also obtained.

Conflict of interest: The authors declare no conflict of interest.

\section{REFERENCES}

Akhtar, M. S., Iqbal, Z., Khan, M. N., \& Lateef, M. (2000). Anthelmintic activity of medicinal plants with particular reference to their use in animals in the Indo-Pakistan subcontinent. Small Ruminant Research, 38(2), 99-107. doi:10.1016/ S0921-4488(00)00163-2

Barbosa, P. C., Cazorla, I. M., Giglio, J. S., \& Strassman, R. (2009). A six-month prospective evaluation of personality traits, psychiatric symptoms and quality of life in ayahuasca-naïve subjects. Journal of Psychoactive Drugs, 41(3), 205-212. doi:10.1080/02791072.2009.10400530

Barker, S. A., McIlhenny, E. H., \& Strassman, R. (2012). A critical review of reports of endogenous psychedelic N, N-dimethyltryptamines in humans: 1955-2010. Drug Testing and Analysis, 4(7-8), 617-635. doi:10.1002/dta.422

Beaton, J. M., \& Christian, S. T. (1977). Stress induced changes in whole brain indolealkylamine levels in the rat: Using gas liquid chromatography-mass spectrometry. Abstracts Society for Neuroscience, 4, 1322.

Bektas, N., Nemutlu, D., \& Arslan, R. (2015). The imidazoline receptors and ligands in pain modulation. Indian Journal of Pharmacology, 47(5), 472-478. doi:10.4103/0253-7613. 165196

Benson, C., Mifflin, K., Kerr, B., Jesudasan, S. J. B., Dursun, S., \& Baker, G. (2015). Biogenic amines and the amino acids GABA and glutamate: Relationships with pain and depression. In D. P. Finn \& B.E. Leonard (Eds.), Pain in psychiatric disorders. Basel, Switzerland: Karger.

Bogenschutz, M. P., Forcehimes, A. A., Pommy, J. A., Wilcox, C. E., Barbosa, P. C., \& Strassman, R. J. (2015). Psilocybin-assisted treatment for alcohol dependence: A proof-of-concept study. Journal of Psychopharmacology, 29(3), 289-299. doi:10.1177/0269881114565144
Boston Scientific. (2013). The painful truth. State of pain management in Europe. Retrieved from http://www.pae-eu.eu/ wp-content/uploads/2013/12/The-state-of-pain-managementin-Europe.pdf

Bruna, J., Videla, S., Argyriou, A. A., Velasco, R., Villoria, J., Santos, C., Nadal, C., Cavaletti, G., Alberti, P., Briani, C., Kalofonos, H. P., Cortinovis, D., Sust, M., Vaqué, A., Klein, T., \& Plata-Salamán, C. (2018). Efficacy of a novel sigma-1 receptor antagonist for oxaliplatin-induced neuropathy: A randomized, double-blind, placebo-controlled phase II clinical trial. Neurotherapeutics, 15(1), 178-189. doi:10.1007/s13311-017-0572-5

Carbonaro, T. M., \& Gatch, M. B. (2016). Neuropharmacology of N, N-dimethyltryptamine. Brain Research Bulletin, 126(1), 74-88. doi:10.1016/j.brainresbull.2016.04.016

Carhart-Harris, R. L., Kaelen, M., Whalley, M. G., Bolstridge, M., Feilding, A., \& Nutt, D. J. (2015). LSD enhances suggestibility in healthy volunteers. Psychopharmacology, 232(4), 785-794. doi:10.1007/s00213-014-3714-z

Carroll, I., Mackey, S., \& Gaeta, R. (2007). The role of adrenergic receptors and pain: The good, the bad, and the unknown. Seminars in Anesthesia, Perioperative Medicine and Pain, 26(1), 17-21. doi:10.1053/j.sane.2006.11.005

Collier, T. L., Waterhouse, R. N., \& Kassiou, M. (2007). Imaging sigma receptors: Applications in drug development. Current Pharmaceutical Design, 13(1), 51-72. doi:10.2174/138161 207779313740

Da Prada, M., Kettler, R., Keller, H. H., Cesura, A. M., Richards, J. G., Saura-Marti, J., Muggli-Maniglio, D., Wyss, P. C., Kyburz, E., \& Imhof, R. (1990). From moclobemide to Ro 19-6327 and Ro 41-1049: The development of a new class of reversible, selective MAO-A and MAO-B inhibitors. Journal of Neural Transmission, 29, 279-292. doi:10.1007/978-3-7091-9050-0_27

Davidson, J. (1985). Monoamine oxidase inhibitors in patients with chronic pain. Archives of General Psychiatry, 42(6), 635-636. doi:10.1001/archpsyc.1985.01790290117018

Deandrea, S., Montanari, M., Moja, L., \& Apolone, G. (2008). Prevalence of undertreatment in cancer pain. A review of published literature. Annals of Oncology, 19(12), 1985-1991. doi:10.1093/annonc/mdn419

de Rios, M. D., Grob, C., \& Baker, J. (2002). Hallucinogens and redemption. Journal of Psychoactive Drugs, 34(3), 239-248. doi:10.1080/02791072.2002.10399960

European Pain Federation. (2018). Cost of chronic pain. Retrieved from https://www.europeanpainfederation.eu/peoplewith-pain/cost-of-chronic-pain/

Ezquerra-Romano, I., Lawn, W., Krupitsky, E., \& Morgan, C. J. A. (2018). Ketamine for the treatment of addiction: Evidence and potential mechanisms. Neuropharmacology, 142, 72-82. doi:10.1016/j.neuropharm.2018.01.017

Farouk, L., Laroubi, A., Aboufatima, R., Benharref, A., \& Chait, A. (2008). Evaluation of the analgesic effect of alkaloid extract of Peganum harmala: Possible mechanisms involved. Journal of Ethnopharmacology, 115(3), 449-454. doi:10.1016/j.jep. 2007.10.014

Fontanilla, D., Johannessen, M., Hajipour, A. R., Cozzi, N. V., Jackson, M. B., \& Ruoho, A. E. (2009). The hallucinogen N, $\mathrm{N}$-dimethyltryptamine (DMT) is an endogenous sigma-1 receptor regulator. Science, 323(5916), 934-937. doi:10.1126/ science. 1166127 
García-Romeu, A., Griffiths, R. R., \& Johnson, M. W. (2014). Psilocybin-occasioned mystical experiences in the treatment of tobacco addiction. Current Drug Abuse Reviews, 7, 157-164. doi:10.2174/1874473708666150107121331

Gereau, R. W., Sluka, K. A., Maixner, W., Savage, S. R., Price, T. J., Murinson, B. B., Sullivan, M. D., \& Fillingim, R. B. (2014). A pain research agenda for the 21 st century. The Journal of Pain, 15(12), 1203-1214. doi:10.1016/ j.jpain.2014.09.004

Glennon, R. A., Dukat, M., Grella, B., Hong, S., Costantino, L., Teitler, M., Smith, C., Egan, C., Davis, K., \& Mattson, M. V. (2000). Binding of $\beta$-carbolines and related agents at serotonin $\left(5-\mathrm{HT}_{2}\right.$ and $\left.5-\mathrm{HT}_{1 \mathrm{~A}}\right)$, dopamine $\left(\mathrm{D}_{2}\right)$ and benzodiazepine receptors. Drug and Alcohol Dependence, 60(2), 121-132. doi:10.1016/S0376-8716(99)00148-9

Greco, M., Roberto, A., Corli, O., Deandrea, S., Bandieri, E., Cavuto, S., \& Apolone, G. (2014). Quality of cancer pain management: An update of a systematic review of undertreatment of patients with cancer. Journal of Clinical Oncology, 32(36), 4149-4154. doi:10.1200/JCO.2014.56.0383

Griesmaier, E., Posod, A., Gross, M., Neubauer, V., Wegleiter, K., Hermann, M., Urbanek, M., Keller, M., \& Kiechl-Kohlendorfer, U. (2012). Neuroprotective effects of the sigma-1 receptor ligand PRE-084 against excitotoxic perinatal brain injury in newborn mice. Experimental Neurology, 237(2), 388-395. doi:10.1016/j.expneurol.2012.06.030

Griffiths, R. R., Johnson, M. W., Richards, W. A., Richards, B. D., Mccann, U., \& Jesse, R. (2011). Psilocybin occasioned mystical-type experiences: Immediate and persisting dose-related effects. Psychopharmacology, 218(4), 649-665. doi:10.1007/ s00213-011-2358-5

Gundlach, A. L., Largent, B. L., \& Snyder, S. H. (1986). Autoradiographic localization of sigma receptor binding sites in guinea pig and rat central nervous system with (+)3H-3-(3-hydroxyphenyl)-N-(1-propyl)piperidine. The Journal of Neuroscience, 6(6), 1757-1770. doi:10.1523/JNEUROSCI. 06-06-01757.1986

Hartogsohn, I. (2016). Set and setting, psychedelics and the placebo response: An extra-pharmacological perspective on psychopharmacology. Journal of Psychopharmacology, 30(12), 1259-1267. doi:10.1177/0269881116677852

Hayashi, T., \& Su, T. P. (2007). Sigma-1 receptor chaperones at the ER-mitochondrion interface regulate $\mathrm{Ca}^{2+}$ signaling and cell survival. Cell, 131(3), 596-610. doi:10.1016/j.cell. 2007.08 .036

Herraiz, T., González, D., Ancín-Azpilicueta, C., Arán, V. J., \& Guillén, H. (2010). $\beta$-carboline alkaloids in Peganum harmala and inhibition of human monoamine oxidase (MAO). Food and Chemical Toxicology, 48(3), 839-845. doi:10.1016/j.fct. 2009.12.019

Herraiz, T., \& Guillén, H. (2011). Inhibition of the bioactivation of the neurotoxin MPTP by antioxidants, redox agents and monoamine oxidase inhibitors. Food and Chemical Toxicology, 49(8), 1773-1781. doi:10.1016/j.fct.2011.04.026

Herraiz, T., Guillén, H., Arán, V. J., \& Salgado, A. (2017). Identification, occurrence and activity of quinazoline alkaloids in Peganum harmala. Food and Chemical Toxicology, 103, 261-269. doi:10.1016/j.fct.2017.03.010

Husbands, S. M., Glennon, R. A., Gorgerat, S., Gough, R., Tyacke, R., Crosby, J., Nutt, D. J., Lewis, J. W., \& Hudson, A. L. (2001). $\beta$-carboline binding to imidazoline receptors. Drug and
Alcohol Dependence, 64(2), 203-208. doi:10.1016/S0376-8716 (01)00123-5

Hyrskyluoto, A., Pulli, I., Tornqvist, K., Ho, T. H., Korhonen, L., \& Lindholm, D. (2013). Sigma-1 receptor agonist PRE084 is protective against mutant huntingtininduced cell degeneration: Involvement of calpastatin and the NF-kB pathway. Cell Death \& Disease, 4(5), e646. doi:10.1038/cddis.2013.170

Institute of Medicine. (2011). Relieving pain in America: A blueprint for transforming prevention, care, education, and research. The National Academies Collection: Reports funded by National Institutes of Health. National Academies Press, Washington, DC.

Jann, M. W., \& Slade, J. H. (2007). Antidepressant agents for the treatment of chronic pain and depression. Pharmacotherapy, 27(11), 1571-1587. doi:10.1592/phco.27.11.1571

Keiser, M. J., Setola, V., Irwin, J. J., Laggner, C., Abbas, A. I., Hufeisen, S. J., Jensen, N. H., Kuijer, M. B., Matos, R. C., Tran, T. B., Whaley, R., Glennon, R. A., Hert, J., Thomas, K. L., Edwards, D. D., Shoichet, B. K., \& Roth, B. L. (2009). Predicting new molecular targets for known drugs. Nature, 462(7270), 175-181. doi:10.1038/nature08506

Kirkpatrick, D. R., McEntire, D. M., Hambsch, Z. J., Kerfeld, M. J., Smith, T. A., Reisbig, M. D., Youngblood, C. F., \& Agrawal, D. K. (2015). Therapeutic basis of clinical pain modulation. Clinical and Translational Science, 8(6), 848-856. doi:10.1111/cts.12282

Kourrich, S., Su, T. P., Fujimoto, M., \& Bonci, A. (2012). The sigma-1 receptor: Roles in neuronal plasticity and disease. Trends in Neuroscience, 35(12), 762-771. doi:10.1016/j.tins. 2012.09.007

Ly, C., Greb, A. C., Cameron, L. P., Wong, J. M., Barragan, E. V., Wilson, P. C., Burbach, K. F., Soltanzadeh Zarandi, S., Sood, A., Paddy, M. R., Duim, W. C., Dennis, M. Y., McAllister, A. K., Ori-McKenney, K. M., Gray, J. A., \& Olson, D. E. (2018). Psychedelics promote structural and functional neural plasticity. Cell Reports, 23(11), 3170-3182. doi:10.1016/j.celrep.2018.05.022

Mahmoudian, M., Jalilpour, H., \& Salehian, P. (2002). Toxicity of Peganum harmala: Review and a case report. Iranian Journal of Pharmacology and Therapeutics, 1, 1-4.

Mannelli, L. C., Ghelardini, C., Calvani, M., Nicolai, R., Mosconi, L., Toscano, A., Pacini, A., \& Bartolini, A. (2009). Neuroprotective effects of acetyl-L-carnitine on neuropathic pain and apoptosis: A role for the nicotinic receptor. Journal of Neuroscience Research, 87(1), 200-207. doi:10.1002/jnr.21815

Marsden, C. D. (1979). Mood and pain: Pain and it chemistry. In G. E. W. Wolstenholme \& M. O’Connor (Eds.), Brain and mind. New York, NY: Excerpta Medica.

McKenna, D., \& Riba, J. (2015). New world tryptamine hallucinogens and the neuroscience of ayahuasca. Current Topics in Behavioral Neuroscience, 36, 283-311. doi:10.1007/7854_ 2016_472

Menkes, D. B., Fawcett, J. P., Busch, A. F., \& Jones, D. (1995). Moclobemide in chronic neuropathic pain: Preliminary case reports. Clinical Journal of Pain, 11(2), 134-138. doi:10.1097/ 00002508-199506000-00008

Mico, J. A., Ardid, D., Berrocosso, E., \& Eschalier, A. (2006). Antidepressants and pain. Trends in Pharmacological Sciences, 27(7), 348-354. doi:10.1016/j.tips.2006.05.004 
Mika, J., Zychowska, M., Makuch, W., Rojewska, E., \& Przewlocka, B. (2013). Neuronal and immunological basis of action of antidepressants in chronic pain - Clinical and experimental studies. Pharmacological Reports, 65(6), 1611-1621. doi:10.1016/S1734-1140(13)71522-6

Moloudizargari, M., Mikaili, P., Aghajanshakeri, S., Asghari, M. H., \& Shayegh, J. (2013). Pharmacological and therapeutic effects of Peganum harmala and its main alkaloids. Pharmacognosy Reviews, 7(14), 199-212. doi:10.4103/09737847.120524

Monsef, H. R., Ghobadi, A., Iranshahi, M., \& Abdollahi, M. (2004). Antinociceptive effects of Peganum harmala L. alkaloid extract on mouse formalin test. Journal of Pharmacy and Pharmaceutical Sciences, 7(1), 65-69.

Munro, G., Hansen, R., \& Mirza, N. (2013). GABA A $_{\text {receptor }}$ modulation: Potential to deliver novel pain medicines? European Journal of Pharmacology, 716(1-3), 17-23. doi:10.1016/j.ejphar.2013.01.070

Nasehi, M., Piri, M., Nouri, M., Farzin, D., Nayer-Nouri, T., \& Zarrindast, M. R. (2010). Involvement of dopamine D1/D2 receptors on harmane-induced amnesia in the step-down Passive Avoidance Test. European Journal of Pharmacology, 634(1-3), 77-83. doi:10.1016/j.ejphar.2010.02.027

National Institute on Drug Abuse. (2018). Opioid crisis. Retrieved from https://goo.gl/75jAXr

Ohsawa, M., Hayashi, S. S., \& Kamei, J. (2010). Effect of acute topical application of $(+)$-pentazocine on the mechanical allodynia in diabetic mice. European Journal of Pharmacology, 641(1), 49-53. doi:10.1016/j.ejphar.2010.05.005

Ono, Y., Tanaka, H., Takata, M., Nagahara, Y., Noda, Y., Tsuruma, K., Shimazawa, M., Hozumi, I., \& Hara, H. (2014). SA4503, a sigma-1 receptor agonist, suppresses motor neuron damage in in vitro and in vivo amyotrophic lateral sclerosis models. Neuroscience Letters, 559, 174-178. doi:10.1016/j.neulet.2013.12.005

Ott, J. (1994). Ayahuasca Analogues: Pangaen Entheogens. Kennewick, WA: Natural Products Co.

Price, D. D., Verne, G. N., \& Schwartz, J. M. (2006). Plasticity in brain processing and modulation of pain. Progress in Brain Research, 157, 333-352. doi:10.1016/S0079-6123(06)57020-7

Riba, J. (2003). Human pharmacology of ayahuasca (Doctoral thesis). Universitat Autònoma de Barcelona, Spain. Retrieved from https://www.tdx.cat/bitstream/handle/10803/5378/jr1de6. pdf? sequence $=1$ \&isAllowed=y

Ruscher, K., Shamloo, M., Rickhag, M., Ladunga, I., Soriano, L., Gisselsson, L., Toresson, H., Ruslim-Litrus, L., Oksenberg, D., Urfer, R., Johansson, B. B., Nikolich, K., \& Wieloch, T. (2011). The sigma-1 receptor enhances brain plasticity and functional recovery after experimental stroke. Brain, 134(3), 732-746. doi:10.1093/brain/awq367

Saavedra, J. M., \& Axelrod, J. (1972). Psychotomimetic $\mathrm{N}$-methylated tryptamines: Formation in brain in vivo and in vitro. Science, 175(4028), 1365-1366. doi:10.1126/science. 175.4028 .1365

Schindler, E. A. D., Wallace, R. M., Sloshower, J. A., \& D'souza, D. C. (2018). Neuroendocrine associations underlying the persistent therapeutic effects of classic serotonergic psychedelics. Frontiers in Pharmacology, 9, 177. doi:10.3389/ fphar.2018.00177

Servillo, L., Giovane, A., Balestrieri, M. L., Cautela, D., \& Castaldo, D. (2012). N-methylated tryptamine derivatives in citrus genus plants: Identification of N, N, N-trimethyltryptamine in bergamot. Journal of Agricultural and Food Chemistry, 60(37), 9512-9518. doi:10.1021/jf302767e

Sibille, K. T., Bartsch, F., Reddy, D., Fillingim, R. B., \& Keil, A. (2016). Increasing neuroplasticity to bolster chronic pain treatment: A role for intermittent fasting and glucose administration? Journal of Pain, 17(3), 275-2811. doi:10.1016/j.jpain. 2015.11.002

Singh, B., \& Sharma, R. A. (2013). Anti-inflammatory and antimicrobial properties of pyrroloquinazoline alkaloids from Adhatoda vasica Nees. Phytomedicine, 20(5), 441-445. doi:10.1016/j.phymed.2012.12.015

Sokmen, A., Jones, B. M., \& Erturk, M. (1999). The in vitro antibacterial activity of Turkish medicinal plants. Journal of Ethnopharmacology, 67(1), 79-86. doi:10.1016/S03788741(98)00189-5

Splettstoesser, F., Bonnet, U., Wiemann, M., Bingmann, D., \& Büsselberg, D. (2005). Modulation of voltage-gated channel currents by harmaline and harmane. British Journal of Pharmacology, 144(1), 52-58. doi:10.1038/sj.bjp.0706024

Stahl, S., Grady, M. M., Moret, C., \& Briley, M. (2005). SNRIs: The pharmacology, clinical efficacy, and tolerability in comparison with other classes of antidepressants. CNS Spectrums, 10(09), 732-747. doi:10.1017/S1092852900019726

Su, T. P., Hayashi, T., Maurice, T., Buch, S., \& Ruoho, A. E. (2010). The sigma-1 receptor chaperone as an inter-organelle signaling modulator. Trends in Pharmacological Sciences, 31(12), 557-566. doi:10.1016/j.tips.2010.08.007

Szabo, A., Kovacs, A., Frecska, E., \& Rajnavolgyi, E. (2014). Psychedelic N, N-dimethyltryptamine and 5-methoxy-N, $\mathrm{N}$-dimethyltryptamine modulate innate and adaptive inflammatory responses through the sigma-1 receptor of human monocyte-derived dendritic cells. PLoS One, 9(8), e106533. doi:10.1371/journal.pone.0106533

Tomohisa, M., Junpei, O., Aki, M., Masato, H., Mika, F., Kazumi, Y., Teruo, H., \& Tsutomu, S. (2015). Possible involvement of the sigma-1 receptor chaperone in chemotherapeutic-induced neuropathic pain. Synapse, 69(11), 526-532. doi:10.1002/ syn. 21844

Tsai, S. Y., Hayashi, T., Harvey, B. K., Wang, Y., Wu, W. W., Shen, R. F., Zhang, Y., Becker, K. G., Hoffer, B. J., \& $\mathrm{Su}$, T. P. (2009). Sigma-1 receptors regulate hippocampal dendritic spine formation via a free radical-sensitive mechanism involving Rac1.GTP pathway. Proceedings of National Academy of Sciences of the United States of America, 106(52), 22468-22473. doi:10.1073/pnas.0909089106

Tuerxun, T., Numakawa, T., Adachi, N., Kumamaru, E., Kitazawa, H., Kudo, M., \& Kunugi, H. (2010). SA4503, a sigma-1 receptor agonist, prevents cultured cortical neurons from oxidative stress-induced cell death via suppression of MAPK pathway activation and glutamate receptor expression. Neuroscience Letters, 469(3), 303-308. doi:10.1016/ j.neulet.2009.12.013

Vela, J. M., Merlos, M., \& Almansa, C. (2015). Investigational sigma-1 receptor antagonists for the treatment of pain. Expert Opinion on Investigational Drugs, 24(7), 883-896. doi:10.1517/ 13543784.2015.1048334

Walker, A. K., Kavelaars, A., Heijnen, C. J., \& Dantzer, R. (2014). Neuroinflammation and comorbidity of pain and depression. Pharmacological Reviews, 66(1), 80-101. doi:10.1124/pr. 113.008144 
Whelan, A., \& Johnson, M. I. (2018). Lysergic acid diethylamide and psilocybin for the management of patients with persistent pain: A potential role? Pain Management, 8(3), 217-229. doi:10.2217/pmt-2017-0068.

Yu, A. M., Idle, J. R., Krausz, K. W., Küpfer, A., \& Gonzalez, F. J. (2003). Contribution of individual cytochrome P450 isozymes to the O-demethylation of the psychotropic beta-carboline alkaloids harmaline and harmine. Journal of Pharmacology and Experimental Therapeutics, 305(1), 315-322. doi:10.1124/ jpet.102.047050

Zamanillo, D., Romero, L., Merlos, M., \& Vela, J. M. (2013). Sigma 1 receptor: A new therapeutic target for pain. European Journal of Pharmacology, 716(1-3), 78-93. doi:10.1016/ j.ejphar.2013.01.068 